\title{
ENRICHING BALADY BREAD USING RED ALGAE (Pterocladia capillacea)
}

\author{
(Received:11.8.2015)
}

\author{
By \\ N. S. Yousef, R. H. Salem, M. H. Abd El-kader* and E. M. E. Abo Zaid \\ Food Science and Technology Department, Faculty of Home Economics, \\ Al- Azhar University, Tanta, Egypt and *Bread and Pastries Research Department, Food Technology \\ Research Institute, Agriculture Research Center, Giza, Egypt.
}

\begin{abstract}
This study aimed to use red algae Pterocladia capillacea as functional food. Red algae was incorporated in the formulations of balady bread at 2,3 and $4 \%$. The effect of supplementation on chemical composition, minerals content, physical, chemical, and sensory properties of balady bread besides, rheological properties of wheat flour were studied. The protein, lipid, ash and fiber contents in red algae were $25.21,2.28,25.13$ and $11.29 \%$, respectively. Red algae was rich in all minerals compared to wheat flour. Only, phosphorous was higher in wheat flour than in red algae. Red algae was rich in the total essential amino acids. Rheological properties indicated that water absorption increased gradually from $54.2 \%$ for the control wheat flour dough to $62.2 \%$ for wheat flour dough supplemented with $4 \%$ red algae. Also, dough development time increased slightly for wheat flour supplemented with different levels of red algae. Balady bread supplemented with $4 \%$ red algae had the highest fiber and ash contents (2.33 and $2.20 \%$, respectively). Supplementation of balady bread with tested red algae led to increasing the minerals content. Firmness values decreased by increasing red algae levels compared to the control balady bread. Organoleptic evaluation indicated that control balady bread and bread supplemented with $2 \%$ red algae exhibited good organoleptic properties score.
\end{abstract}

Key words: Pterocladia capillacea, functional food, balady bread, physical and chemical properties.

\section{INTRODUCTION}

Balady bread is one of the most important constituents of the Egyptian diet representing the main diet component for rich and poor Egyptian consumers. According to Danesi et al. (2010), algae powder can be added to improve the nutritional value of bread; it has high amounts of vitamins, microelements, especially the active biological materials. In macrobiotic diet, the intake of sea vegetables is $5 \%$ or less of the total daily amount of food (Kushi, 1986). The western diet recommended consuming about $29 \mathrm{~g}$ of algae weekly as a food supplement (about $4 \mathrm{~g} /$ day) which is in agreement with the recent macrobiotic recommendations (Drum, 2003).

The red algae Pterocladia capillacea, contains a significant amount of soluble polysaccharides like agar, alginate and carrageenan which are widely used in the food industry as gelling or thickening agents in marmalade, ice creams, jellies, etc. (Plaza et al., 2008). There is an interest in macro-algae hydrocolloids for human nutrition as they can act as dietary fiber, their physiological effects being closely related to their physicochemical properties such as solubility,viscosity, hydration, and ion-exchange capacities in the digestive tract. Red macro-algae in a source of bioactive compounds are helpful as antioxidant, antibacterial and antiviral activities (Lahaye and Kaeffer, 1997).

The available information on possible toxic properties or any other adverse effects of the red algae tested so far, stated that none of this algae showed any negative effect. All tests, including human studies, failed to reveal any evidence that would restrict the utilization of properly processed algal material (Chamorro, 1980).

The present study aimed to use the red algae (Pterocladia capillacea) as functional food supplementation, determine the acceptability level of supplementation algae powder in special balady bread for some categories and estimate the chemical and physical qualities of the bread product. 


\section{MATEREIALS AND METHODS \\ 2.1. MATERIALS}

Red macro algae Pterocladia capillacea was obtained from Alexandria shore by Edfina Company during May 2013. Wheat flour (82\% extraction) was obtained from Boric El- Hagar stone mill, West Delta Flour Mills Company at Tanta City, El- Gharbia Governorate, Egypt.

\subsection{METHODS}

\subsubsection{Preparation of red algae}

Red algae was washed by fresh tap water to remove all mechanical impurities and water soluble substances, followed by air drying. Then, it was softened according to Imada and Takahshi (1986). In this method washed and dried algae was boiled under atmospheric pressure with 3\% acetic acid solution for 10 minutes. The liquid phase drained, algae was washed and sun dried for 3 days. The dried samples were ground to fine powder and stored in low density polyethylene bags at room temperature $\left(37^{\circ} \mathrm{C}\right)$ for further uses.

\subsubsection{Preparation of balady bread}

Balady bread control was made with $100 \%$ wheat flour ( $82 \%$ extraction), $1.5 \%$ activated compressed yeast, $1.5 \%$ sodium chloride and 75 $80 \mathrm{ml}$ water $/ 100 \mathrm{~g}$ flour according to Yasseen (1985). Algae were added to wheat flour at substitution levels of 2,3 and $4 \%$. The ingredients were mixed for $20 \mathrm{~min}$ by hand to form balady bread dough and left to ferment for $1 \mathrm{~h}$ at $30^{\circ} \mathrm{C}$, then divided into $125 \mathrm{~g} /$ pieces. Each piece was molded on a wooden board previously covered with a fine layer of bran and left to ferment for $45 \mathrm{~min}$ at the same mentioned temperature. The fermented dough pieces were flattened to about $20 \mathrm{~cm}$ diameter, then baked at $400 \pm 5^{\circ} \mathrm{C}$ for $3-5 \mathrm{~min}$. by electric oven(UNOX, XBC605, Made in Italy). The loaves of bread were allowed to cool on racks for about $2 \mathrm{hrs}$ before evaluation.

\subsubsection{Chemical composition}

The moisture, ether extract, total nitrogen, ash content, crude fiber contents were determined according to the methods described by A.O.A.C. (2000). Carbohydrate contents were calculated by difference. Energy value was calculated according to the method of Mahgoub (1999).

\subsubsection{Minerals contents}

Mineral contents of ash were determined using common methods described by A.O.A.C. (2000). Sodium and potassium were determined by flame photometry (Model 405 Corning, Halstead Essex, UK), while magnesium, calcium, zinc, manganese, iron, nickel, cadmium, lead and copper were determined using atomic absorption spectrophotometry (Perkin-Elmer, Model 403 Norwalk, Connecticut, USA). Phosphorus and iodine were determined calorimetrically (Spectronic 20 Gallenkamp, London, UK) .

\subsubsection{Amino acids profile}

Amino acids composition was determined according to the method described by Ozols (1990) using Beckman amino acid analyzer (Model 119 CL).

Amino acid score was calculated according to the method of FAO/WHO/UNU (2002) as follows:

Amino acid score

$$
=\frac{\mathrm{mg} \text { of amino acid in } 1 \mathrm{~g} \text { test protein }}{\mathrm{mg} \text { of amino acid in requirement pattern }}
$$

\subsubsection{Rheological properties of bread dough}

2.2.6.1. Farinograph and Extensograph parameters were determined using Brabender equipments as the methods described by $\mathrm{A}$. A.C.C. (2000).

2.2.6.2. Falling number was determined according to the method described in A.A.C.C. (2000) and liquefaction number was calculated according to Finney (2001) as follow:

$$
\text { Liquefaction Number }=\frac{6000}{\text { Falling number }-50}
$$

2.2.6.3. Falling time was calculated according to Kent-Jones and Amos (1967).

\subsubsection{Determination of gluten}

Wet, dry gluten and gluten index of wheat flour were determined using Glutomatic perten instruments (AB type2200 No. 005092, Huddling, Sweden) as described by Perten (1990).

2.2.7. Texture profile was determined as mentioned by Bourne (2002).

\subsubsection{Sensory evaluation of balady bread}

The organoleptic properties of balady bread samples were carried out according to El-Farra et al. (1982). Balady bread samples were subjected to sensory evaluation by ten members of Food Science and Technology Department, Faculty of Home Economics, Al-Azher Univ., Tanta. Each sample was sensorial evaluated for general appearance (15), crust color (15), crumb color (15), odor (15), taste (15), roundness (15), separation of layer (10) and overall acceptability (100).

\subsubsection{Statistical Analysis}

The statistical analysis was carried out using SPSS. Statistical software (version 11.0 SPSS inc., Chicago, USA), the results were expressed 
as means. Data were subjected to analysis of variance (ANOVA). The differences between means were tested for significance using Duncan's test at $(\mathrm{p} \leq 0.05)$ according to Armitage and Berry (1987).

\section{RESULTS AND DISCUSSION}

3.1. Chemical composition of tested wheat flour and red algae

Data in Table (1) recorded that, the highest contents of moisture, carbohydrate and energy were found in wheat flour. On the other hand, the highest contents of protein, lipid, ash and crude fiber were found in red algae.

These results were in agreement with those found by Khairy and El-Shafay (2013), who reported that the red algae Pterocladia capillacea, contained $23 \%$ protein, $37 \%$ ash, $10 \%$ fiber and $28 \%$ carbohydrates.

Table (1) : Chemical composition of the tested wheat flour and red algae (as dryweight basis)

\begin{tabular}{|l|c|c|}
\hline Components\% & $\begin{array}{c}\text { Wheat flour } \\
82 \% \\
\text { extraction }\end{array}$ & $\begin{array}{c}\text { Red algae } \\
\text { P. capillacea }\end{array}$ \\
\hline Moisture & 12.27 & 8.64 \\
\hline Protein & 12.54 & 25.21 \\
\hline Lipid & 1.83 & 2.28 \\
\hline Ash & 1.30 & 25.13 \\
\hline Crude fiber & 1.81 & 11.29 \\
\hline Carbohydrates & 82.52 & 36.09 \\
\hline Energy (kcal/100g) & 396.71 & 265.72 \\
\hline
\end{tabular}

\subsection{Amino acid contents and amino acid scores of red algae}

From Table (2), it could be noticed that $P$. capillacea is rich in total essential amino acids $(36.84 \%)$. This value was higher than that given by the recommended pattern FAO/WHO (1991) for preschool children groups. These results are in agreement also with Kovac et al. (2013).

At the same time, isoleucine, leucine, lysine and valine were higher in red algae than those given by the recommended pattern (FAO/WHO, 1991) for preschool children group.

Also, the results presented in Table (2) showed that, methionine was the first limiting amino acid in red algae $(0.20)$. Valine had the highest amino acid score among all the essential amino acids with value of 2.18 followed by isoleucine (1.76). These results are in agreement with Murata and Nakazoe (2001) who reported that the amino acid scores of the proteins of algae ranged from $60 \%$ to $100 \%$ and these values were higher than that of the proteins of cereals and vegetables.

\subsection{Mineral contents of tested wheat flour and red algae}

Red algae were rich in all minerals compared to the tested wheat flour (Table 3). Only, phosphorous was higher in the tested wheat flour $(171.41 \mathrm{mg} / 100 \mathrm{~g})$ than in red algae $121 \mathrm{mg} / 100 \mathrm{~g}$. Furthermore, mineral contents in red macro algae were higher than those in edible land plants and animal products (Rupérez, 2002). Creeksong (2003) reported that, the sea vegetables are effective in relatively small supplementary amounts and can supply our food with many missing elements.

Whitney and Rolfes (1996) mentioned that the basic component in macro algae is iodine, as essential trace element and integral part of two hormones released by the thyroid gland.

*Source of daily requirements of preschool children (Food and Nutrition Board, 2012)

As shown in Table (3), iodine content was $23.7 \mathrm{mg} / 100 \mathrm{~g}$ for red algae. The recommended daily dose for preschool children is $0.09 \mathrm{mg}$ of iodine (Food and Nutrition Board, 2012). The intake of red algae per day would supply 0.948 $\mathrm{mg}$ of iodine.

Some heavy metals such as cadmium, nickel and lead were found to be $0.4,34.78$ and 0.304 $\mathrm{mg} / 100 \mathrm{~g}$, respectively. This revealed that red algae in the present study can be considered as a safe product for consumption (Ortega-Calvo et al., 1993).

3.4. Farinograph, Extensograph parameters and gluten quality of composite wheat flour with different levels of red algae

Water absorption increased gradually by increasing the replacement levels of red algae. It increased from $54.2 \%$ for the control to $62.2 \%$ for dough supplemented with $4 \%$ red algae as shown in Table (4).

\section{B. $\mathbf{U}=$ Brabender unit}

These results may be due to the high fiber content in red algae (11.29\%). This fact has been emphasized by dough weakening data with increasing of supplementation levels of red algae. Leon et al. (2000) mentioned that using of Kappa carrageenan (sulphated polysaccharide extracted from certain red algae ) as a dough additive, has an ability to improve the specific volume of the bread due to its interactions with gluten proteins. 
Table (2): Amino acid contents and amino acid scores of red algae.

\begin{tabular}{|l|c|c|c|}
\hline $\begin{array}{c}\text { Amino acids } \\
\text { (g/100g protein) }\end{array}$ & P.capillacea & $\begin{array}{c}\text { FAO/WHO for } \\
\text { preschool } \\
\text { children }\end{array}$ & $\begin{array}{c}\text { Amino acid } \\
\text { score }\end{array}$ \\
\hline Histidine & 1.38 & 1.9 & 0.73 \\
\hline Isoleucine & 4.94 & 2.8 & 1.76 \\
\hline Leucine & 7.58 & 6.6 & 1.15 \\
\hline Lysine & $\mathbf{7 . 0 6}$ & 5.8 & 1.22 \\
\hline Methionine & $\mathbf{0 . 5 0}$ & $\mathbf{2 . 5}$ & $\mathbf{0 . 2 0}$ \\
\hline Phenylalanine & $\mathbf{2 . 9 2}$ & $\mathbf{2 . 8}$ & 1.04 \\
\hline Tyrosine & 2.43 & 3.5 & 0.69 \\
\hline Threonine & 2.41 & 3.4 & 0.71 \\
\hline Valine & $\mathbf{7 . 6 2}$ & 3.5 & 2.18 \\
\hline $\begin{array}{l}\text { Total essential } \\
\text { amino acids }\end{array}$ & 36.84 & 32.8 & \\
\hline
\end{tabular}

*First limiting amino acid

Table(3): Mineral contents in wheat flour and red algae compared with the recommended daily dose for preschool children.

\begin{tabular}{|c|c|c|c|c|}
\hline $\begin{array}{c}\text { Minerals } \\
(\mathrm{mg} / \mathbf{1 0 0 g})\end{array}$ & $\begin{array}{l}\text { Wheat } \\
\text { flour }\end{array}$ & $\begin{array}{c}P . \\
\text { capillacea }\end{array}$ & $\begin{array}{c}\text { *Daily } \\
\text { requirement } \\
(\mathrm{mg}) \\
\text { for preschool } 1-3 \mathrm{y}\end{array}$ & $\begin{array}{c}\text { P.capillacea } \\
\text { Intake(mg) } \\
\text { (4\%substitute) } \\
\end{array}$ \\
\hline \multicolumn{5}{|l|}{ Major minerals } \\
\hline Calcium & 26.21 & 743 & 700 & 29.72 \\
\hline Phosphorous & 170.41 & 121 & 460 & 4.84 \\
\hline Sodium & 34.76 & 2200 & 1005 & 88.0 \\
\hline Potassium & 116.38 & 1764 & 3000 & 70.56 \\
\hline Magnesium & --- & 230 & 80 & 9.2 \\
\hline \multicolumn{5}{|l|}{ Trace minerals } \\
\hline Iron & 2.05 & 100 & 7 & 4.0 \\
\hline Zinc & & 70 & 3 & 2.8 \\
\hline Copper & & 3.20 & 0.34 & 0.128 \\
\hline Iodine & & 23. 70 & 0.09 & 0.948 \\
\hline Manganese & & 10.50 & 1.2 & 0.42 \\
\hline \multicolumn{5}{|l|}{ Heavy metals } \\
\hline Cadmium & & 0.40 & & \\
\hline Nickel & & 34.78 & & \\
\hline Lead & & 0.304 & & \\
\hline
\end{tabular}


Table(4): Farinograph, Extensograph parameters and gluten quality of tested wheat flour supplemented with different levels of red algae.

\begin{tabular}{|l|c|c|c|c|}
\hline \multirow{2}{*}{ Parameter } & \multirow{2}{*}{ Control } & \multicolumn{2}{c|}{ Red algae supplementation level, \% } \\
\cline { 2 - 5 } & & 2 & 3 & 4 \\
\hline \multicolumn{5}{|c|}{ Farinograph data } \\
\hline Water absorption (\%) & 54.2 & 60.0 & 61.5 & 62.2 \\
\hline Arrival time (min) & 0.5 & 0.5 & 0.5 & 0.5 \\
\hline Dough development (min) & 1.0 & 2.0 & 1.5 & 1.5 \\
\hline Dough stability (min) & 9.5 & 7.0 & 5.5 & 5.0 \\
\hline Dough weakening (B.U) & 80 & 100 & 110 & 120 \\
\hline & Extensograph data & & \\
\hline Elasticity (B.U) & 260 & 210 & 160 & 140 \\
\hline Extensibility (mm) & 150 & 145 & 125 & 120 \\
\hline Proportional number (P.N) & 1.73 & 1.45 & 1.28 & 1.16 \\
\hline Energy (cm ${ }^{2}$ ) & 26 & 25 & 25 & 23 \\
\hline & Gluten quality & & \\
\hline Wet gluten, \% & 32.21 & 28.01 & 27.91 & 20.83 \\
\hline Dry gluten, \% & 11.01 & 9.79 & 9.14 & 7.75 \\
\hline Gluten index, \% & 83.96 & 78.32 & 77.47 & 76.39 \\
\hline
\end{tabular}

Similar results were observed by Rosell et al. (2001) who reported that the differences in water absorption are mainly caused by the great number of hydroxyl groups which exist in the fiber structure and allow more water interactions through hydrogen bonding.

The dough development time in both the control dough and the dough supplemented with different levels of red algae increased slightly. Dough stability was higher in the control sample (9.5min)than other dough samples supplemented with different levels of red algae. Rosell et al.(2001) reported that stability of wheat flour dough is an indicator of the flour strength and the higher values point to stronger dough. Similar results were reported by Sudha et al. (2007).

The results in Table (4) showed that wheat flour supplemented with red algae at different levels minimized the extensibility. This decrement might be due to the deficiency of gliadin and glutenin in algae powders. These results are in line with those reported by Hafez (1996).

The proportional number (P.N) (ratio between dough elasticity and dough extensibility) decreased with increasing the levels of red algae from 1.73 for the control to
1.16 for samples supplemented with $4 \%$ red algae. Energy ranged between $26 \mathrm{~cm}^{2}$ for the control and $23 \mathrm{~cm}^{2}$ for dough supplemented with $4 \%$ red algae. These results are in agreement with those obtained by Jones and Erlander (1967).

The highest wet gluten was presented in the control $(32.21 \%$ ), while the lowest value was found in wheat flour supplemented with $4 \%$ red algae $(20.83 \%)$. So that, gluten content was decreased by increasing the levels of red algae, the results appropriate to the absence of glutenin and gliadin in algae. The obtained results agree with those reported by Hassan et al. (2011).

From the results presented in Table (4), it could be also noticed that the control had the highest gluten index $(83.96 \%)$, while wheat flour supplemented with $4 \%$ red algae had the least value of gluten index $(76.39 \%)$.

\subsection{Falling number of wheat flour samples} supplemented with different levels of red algae.

Addition of different levels of red algae to wheat flour increased the falling number value and falling time compared with the control sample (Table 5). Falling number was $270 \mathrm{sec}$ for the control sample, while it was $288 \mathrm{sec}$ for wheat flour supplemented with $4 \%$ red algae. 
Table (5): Falling number of wheat flour supplemented with different levels of red algae.

\begin{tabular}{|l|c|c|c|c|}
\hline \multirow{2}{*}{\multicolumn{1}{|c|}{ Parameter }} & \multirow{2}{*}{ Control } & \multicolumn{3}{c|}{ Red algae supplementation level, \% } \\
\cline { 3 - 5 } & & 2 & 3 & 4 \\
\hline Falling number, sec & 270 & 272 & 286 & 288 \\
\hline Falling time, sec & 210 & 212 & 226 & 228 \\
\hline Liquefaction number, \% & 27.27 & 27.03 & 25.42 & 25.21 \\
\hline
\end{tabular}

On the other hand, the liquefaction number was decreased by increasing supplementation ratios with red algae. This means that, addition of different levels from red algae decreased the alpha-amylase in wheat flour by substitute red algae in samples.

\subsection{Chemical composition of balady bread samples}

There were significant differences $(\mathrm{P} \leq 0.05)$ between the control balady bread samples and other samples supplemented with different levels of red algae for all constituents (Table 6). Moisture content increased by increasing of red algae supplementation levels. It may be due to hydrocolloids in algae. These results were in agreement with Gray and Bemiller (2003) who reported that hydrocolloids were added to bakery products to extend their shelf-life by keeping the moisture content and retarding the staling during storage. Selomulyo and Zhou,(2007) reported that the presence of this hydrocolloid increased the moisture content in the final bread.

No significant differences were observed in the total lipid content between supplemented balady bread samples. Protein, fiber and ash contents were increased gradually by increasing the levels of red algae. The protein, fiber and ash contents of balady bread samples ranged from $10.54,1.82$ and $1.68 \%$ for the control to 11.19 , 2.33 and $2.2 \%$ for bread supplemented with $4 \%$ red algae, respectively. This could be attributed to high content of protein, fiber and ash content of the added red algae (Table 1). Nguyen (2014) found that protein, lipid, carbohydrates, calcium, iron, phosphore and energy of bread prepared with $3 \%$ spirulina were, $11.0 \%, 5.7 \%, \quad 54.2 \%, 90.0 \mathrm{mg} / 100 \mathrm{gm}$, $2.7 \mathrm{mg} / 100 \mathrm{gm}, 125.0 \mathrm{mg} / 100 \mathrm{gm}$ and 312.1 $\mathrm{Kcal} / 100 \mathrm{gm}$, respectively .

According to Becker (2007) cereal such as wheat flour is low in protein content, but algae are considered a source of protein. Hence the consumption of balady bread supplemented with algae means eating bread with higher protein content and improved protein quality. Total carbohydrate contents of balady bread samples supplemented with different levels of red algae were significantly lower than the control sample.

Means of energy values ranged between $389.88 \mathrm{kcal} / 100 \mathrm{~g}$ for balady bread supplemented with $4 \%$ red algae and $393.05 \mathrm{kcal} / 100 \mathrm{~g}$ for the control.

\subsection{Mineral contents of balady bread samples}

Data in Table (7) illustrated that, calcium content in the control balady bread was 38.70 $\mathrm{mg} / 100 \mathrm{~g}$. Supplemented balady bread with tested red algae led to an increase in calcium content. The increment percentages of $\mathrm{Ca}$ were $128.10 \%$ when wheat flour was replaced with $4 \%$ red algae. So that the addition of red algae to balady bread appeared more effective in increasing Ca content (Devi et al., 2011). On the other hand, control sample had the lowest $\mathrm{Ca}, \mathrm{P}$, $\mathrm{Fe}$ and $\mathrm{K}$ content when compared with balady bread supplementation with different levels of red algae. The highest K content (297.48 $\mathrm{mg} / 100 \mathrm{~g}$ ) was recorded for balady bread supplemented with $4 \%$ red algae.

\subsection{Texture profile of balady bread samples}

From Table (8), it could be observed that firmness values were decreased by increasing of red algae levels compared to the control balady bread. It may be due to the increase in protein and fiber contents by the addition of red algae. Hydrocolloids when used in small quantities $(<1 \% \mathrm{w} / \mathrm{w}$ in flour) are expected to increase water retention and decrease firmness and starch retrogradition (Collar et al., 1999).

These results are in contrast with those obtained by Sangnark and Noomhorn (2004) who found that high protein and fiber ingredients added into bread formulation increased the hardness of bread. Thus, the red algae used in the present study caused differences on firmness parameter of balady bread samples. 
Table (6): Chemical composition of balady bread supplemented with different levels of red algae.

\begin{tabular}{|c|c|c|c|c|}
\hline \multirow{2}{*}{$\begin{array}{c}\text { Components } \\
(\%)\end{array}$} & \multirow{2}{*}{ Control } & \multicolumn{3}{|c|}{ Red algae supplementation level, \% } \\
\hline & & 2 & 3 & 4 \\
\hline Moisture & $34.14^{\mathrm{c}}$ & $34.47^{b}$ & $\mathbf{3 4 . 5 3}^{\mathrm{a}}$ & $34.54^{\mathrm{a}}$ \\
\hline Protein & $10.54^{d}$ & $10.78^{c}$ & $11.03^{b}$ & $11.19^{a}$ \\
\hline Lipid & $1.41^{\mathrm{b}}$ & $1.55^{\mathrm{a}}$ & $1.58^{\mathrm{a}}$ & $1.60^{\mathrm{a}}$ \\
\hline Fiber & $1.82^{\mathrm{c}}$ & $2.17^{b}$ & $2.27^{\mathrm{a}}$ & $2.33^{\mathrm{a}}$ \\
\hline Ash & $1.68^{d}$ & $1.94^{\mathrm{c}}$ & $2.07^{b}$ & $2.20^{\mathrm{a}}$ \\
\hline Carbohydrates & $84.55^{a}$ & $83.56^{b}$ & $83.05^{c}$ & $82.68^{d}$ \\
\hline Energy(Kcal/100gm) & $393.05^{\mathrm{a}}$ & 391.31 $^{\mathrm{b}}$ & $390.54^{\mathrm{c}}$ & 389.88 \\
\hline
\end{tabular}

In a row, means having the same superscript letters are not significantly different at $5 \%$ level.

Table (7): Mineral contents of balady bread supplemented with different levels of red algae.

\begin{tabular}{|c|c|c|c|c|}
\hline \multirow{2}{*}{ Treatments } & \multicolumn{4}{|c|}{ Minerals, $\mathbf{m g} / \mathbf{1 0 0 g}$} \\
\cline { 2 - 5 } & Ca & K & P & Fe \\
\hline Control & 38.70 & 237.02 & 264.64 & 2.59 \\
\hline Red algae levels, \% & & & & \\
\hline 2 & 58.25 & 260.11 & 276.54 & 2.68 \\
\hline 3 & 78.03 & 284.64 & 292.30 & 2.80 \\
\hline 4 & $\mathbf{8 8 . 2 7}$ & 297.48 & 311.37 & 2.91 \\
\hline
\end{tabular}

Table (8): Texture profile of balady bread supplemented with different levels of red algae.

\begin{tabular}{|l|c|c|c|c|}
\hline \multirow{2}{*}{ Texture profile } & \multirow{2}{*}{ Control } & \multicolumn{3}{|c|}{ Red algae supplementation level, \% } \\
\cline { 3 - 5 } & & $\mathbf{2}$ & $\mathbf{3}$ & $\mathbf{4}$ \\
\hline Firmness (N) & $\mathbf{6 . 8 6 0}$ & $\mathbf{5 . 9 8 0}$ & $\mathbf{4 . 9 5 0}$ & $\mathbf{4 . 7 8 0}$ \\
\hline Cohesiveness & $\mathbf{0 . 5 4 1}$ & $\mathbf{0 . 5 5 5}$ & $\mathbf{0 . 5 9 4}$ & $\mathbf{0 . 6 0 7}$ \\
\hline Gumminess (N) & $\mathbf{3 . 8 0 7}$ & $\mathbf{2 . 9 5 4}$ & $\mathbf{2 . 5 2 7}$ & $\mathbf{2 . 1 3 7}$ \\
\hline Chewiness (Nm) & $\mathbf{2 . 4 5 5}$ & $\mathbf{1 . 7 5 1}$ & $\mathbf{1 . 4 8 5}$ & $\mathbf{1 . 2 0 3}$ \\
\hline Springiness (mm) & $\mathbf{0 . 6 4 5}$ & $\mathbf{0 . 5 9 3}$ & $\mathbf{0 . 5 8 8}$ & $\mathbf{0 . 5 6 3}$ \\
\hline Resilience & $\mathbf{0 . 3 8 9}$ & $\mathbf{0 . 3 7 9}$ & $\mathbf{0 . 3 7 8}$ & $\mathbf{0 . 3 4 2}$ \\
\hline
\end{tabular}

The internal resistance of bread crumb is evaluated by cohesiveness. The results presented in Table (8) showed that, cohesiveness values for balady bread samples supplemented with red algae were higher than those of control sample. The highest cohesiveness value (0.607) was found for balady bread supplemented with $4 \%$ red algae.

From the same results, it could be observed that chewiness values of the bread generally followed a similar trend of firmness. Chewiness is one of the texture parameters easily correlated with sensory analyses through the panels (Gomez et al., 2007). The least chewiness value $(1.203 \mathrm{Nm})$ was recorded for balady bread supplemented with $4 \%$ red algae.

Springiness values of all treatments were decreased as the addition of red algae increased. The lowest springiness value (0.563) was recorded by balady bread supplemented with $4 \%$ red algae.

Resilience values were slightly higher in the control balady bread than in balady bread supplemented with different levels of red algae. Resilience values were low fights to regain its original position in balady bread supplemented with different levels of red algae than the control.

3.9. Organoleptic properties of balady bread samples

Organoleptic properties of balady bread supplemented with red algae at different levels are shown in Table (9).There were no significant differences between the control balady bread 
Table (9): Organoleptic properties of balady bread supplemented with different levels of red algae

\begin{tabular}{|l|c|c|c|c|}
\hline \multirow{2}{*}{\multicolumn{1}{c|}{ Parameter }} & \multirow{2}{*}{ Control } & \multicolumn{3}{c|}{ Red algae supplementation level, \% } \\
\cline { 3 - 5 } & & $\mathbf{2}$ & $\mathbf{3}$ & $\mathbf{4}$ \\
\hline General appearance (15) & $14.33 \pm 0.7^{\mathbf{a}}$ & $14.55 \pm 0.5^{\mathbf{a}}$ & $14.22 \pm 0.4^{\mathbf{a}}$ & $13.11 \pm 0.6^{\mathbf{b}}$ \\
\hline Crust color (15) & $14.55 \pm 0.3^{\mathbf{b}}$ & $14.83 \pm 0.2^{\mathbf{a}}$ & $14.61 \pm 0.2^{\mathbf{a b}}$ & $14.16 \pm 0.3^{\mathbf{c}}$ \\
\hline Crumb color (15) & $14.70 \pm 0.2^{\mathrm{a}}$ & $13.30 \pm 0.3^{\mathrm{b}}$ & $13.07 \pm 0.05^{\mathbf{c}}$ & $12.64 \pm 0.1^{\mathrm{d}}$ \\
\hline Roundness(15) & $14.55 \pm 0.4^{\mathbf{a}}$ & $14.72 \pm 0.3^{\mathbf{a}}$ & $14.55 \pm 0.1^{\mathbf{a}}$ & $14.44 \pm 0.3^{\mathbf{a}}$ \\
\hline Taste (15) & $14.55 \pm 0.5^{\mathbf{a}}$ & $14.38 \pm 0.6^{\mathbf{a}}$ & $13.88 \pm 0.3^{\mathbf{b}}$ & $13.11 \pm 0.7^{\mathbf{c}}$ \\
\hline Odor (15) & $14.72 \pm 0.3^{\mathbf{a}}$ & $13.77 \pm 0.3^{\mathbf{b}}$ & $13.53 \pm 0.2^{\mathbf{b}}$ & $13.15 \pm 0.1^{\mathbf{c}}$ \\
\hline Separation of layer (10) & $9.44 \pm 0.5^{\mathbf{a}}$ & $8.05 \pm 0.7^{\mathbf{b}}$ & $7.93 \pm 0.05^{\mathbf{b}}$ & $7.62 \pm 0.2^{\mathbf{b}}$ \\
\hline Overall acceptability (100) & $96.84^{\mathbf{a}}$ & $93.60^{\mathbf{b}}$ & $91.79^{\mathbf{c}}$ & $81.37^{\mathrm{d}}$ \\
\hline
\end{tabular}

In a row, means having the same superscript letters are not significantly different at $5 \%$ level.

sample and balady bread supplemented with 2 and $3 \%$ red algae for most of the evaluated characteristics. The mean of general appearance value was the highest in balady bread supplemented with $2 \%$ red algae (14.55).

From the statistical analysis of sensory evaluation, it could be observed that, there were no significant differences in crust color between control balady bread and other samples supplemented with 2 , and $3 \%$ red algae. The results showed that balady bread supplemented with $2 \%$ red algae had the highest scores.

About crumb color, there were significant differences between samples. However, the control sample showed the highest mean score (14.70). There were no significant differences $(\mathrm{p}<0.05)$ for roundness between control sample and other balady bread samples supplemented with different levels of red algae. Also, no significant differences $(\mathrm{p} \leq 0.05)$ were recorded for taste scores between control and balady bread supplemented with $2 \%$ red algae. Balady bread samples with $4 \%$ red algae had the lowest taste score (13.11). These effects may be related to the increase of fiber content of the red algae which affected taste of bread (Hussein et al., 2013).

The highest mean values of odor, separation layer and overall acceptability were recorded for control balady bread followed by balady bread supplemented with $2 \%$ red algae. From the same results, it could be observed that, the control sample and balady bread supplemented with $2 \%$ red algae, exhibited good organoleptic properties scores. While, the balady bread supplemented with $3 \%$ red algae become in the second degree.
Nguyen (2014) mentioned that the sensory evaluation of bread supplemented with 1,2 and $3 \%$ Spiraling caused a decrease in color, aroma and taste .

From the above results it could be recommended that the addition of $P$. capillacea to wheat flour up to $2 \%$ will give bread without changing in its organoleptic properties.

These results showed that, red algae are important sources for protein, fiber, ash and total soluble carbohydrates. Edible red algae could be used as a food supplement to meet the recommended daily preschool children intakes of some macro minerals and trace elements.

\section{REFERENCES}

A.A.C.C. (2000). American Association of Cereal Chemists. Published by American Association of Cereal Chemists, $10^{\text {th }} \mathrm{Ed}$. International Saint Paul,Minnesota, USA.

A.O.A.C. (2000).Association of Official Analytical Chemists.Official methods of analysis $17^{\text {th }} \mathrm{Ed}$. Gaithersburg MD. USA.

Armitage P. and Berry G. (1987). Statistical methods in Medical Research- Blackwell, Oxford, UK, 93-213.

Becker E.W. (2007). Microalgae as a source of protein. Biotech. Adv. 25(2): 207-210.

Bourne M. (2002). Food Texture and Viscosity: Concept and Measurement. $2^{\text {nd }}$ Ed. Academic Press, New York, USA.

Chamorro G. (1980). Etude toxicologique de l'algue Spirulina plante pilote productrice de protéines (Spirulina de Sosa Texcoco S.A.)UF/MEX/78/048, UNIDO/10.387.

Collar C., Andreu P., Martinez J.C. and Armero E. (1999). Optmiztion of hydrocolloid 
addition to improve wheat bread dough functionally: A response surface methodology study. Food Hydrocolloid, 13: $467-475$

Creeksong D. (2003). Ocean Vegetables for Health, The Grain \& Salt Society, http://www.celticseasalt.com/ocvegforheal.ht $\mathrm{ml}$.

Danesi E., Navacchi M., Takeuchi K.,Frata M., Carlos J. and Carvalho M.(2010). Application of Spirulin aplatensisin protein enrichment of manico based bakery products. J. Biotech., 150: 311.

Devi B.Ch., Singh S.N.K., Singh R.N., Sudarshan M., Chakraborty A. and Ram S.S. (2011). Trace elements in nungsham, the red edible algae of Manipur. Inter'l J. Appl. Biol. and Pharma. Technology, 2 (1): 198-203.

Drum R. (2003). Sea Vegetables for Food and Medicine,

http://www.Partnereartheducationcenter.c om/sexpan1.html

El-Farra A.A., Korshid A.M., Mansour S.M. and Galal A.M. (1982). Studies on the possibility of supplementation of balady bread with various commercial soy products. $1^{\text {st }}$ Egyptian Conference on Bread Research, 9-11 Nove., Giza, Egypt. 9-23.

FAO/WHO (1991). Protein Quality Evaluation, Report of Joint FAO/WHO Expert Consultation. FAO Food and Nutrition Paper 51.FAO/WHO, Rome, Italy.

FAO/WHO/UNU(2002). Protein and amino acid requirements in human nutrition : report of a joint $\mathrm{FAO} / \mathrm{WHO} / \mathrm{UNU}$ expert consultation.(WHO technical report series;no. 935), (Geneva, Switzerland).

Food and Nutrition Board, (2012). Dietary Reference Intakes (DRIs): Recommended Dietary Allowances and Adequate Intakes, Elements. www.nap.edu

Finney P.L. (2001). Effects of falling-number sample weight on prediction of $\alpha$-amylase activity. Cereal Chem.., 78 (4): 485-487.

Gomez M.,Ronda F., Caballero P.A.,Blanco C. A. and Rosell C.M. (2007). Functionality of different hydrocolloids on the quality and shelf-life of yellow layer cakes. Food Hydrocolloids, 21 (2): 167-173.

Gray J.A. and Bemiller J.N. (2003). Bread staling: molecular basis and control. Compr. Rev. in Food Scie. and Food Safety, 2 (1): 1-21.
Hafez S.A. (1996). Effect of adding defatted soy flour on the chemical composition and physical properties of bread. Egyptian J. Agric. Res., 72: 409.

Hassan H.A., Mustafa A.I. and Ahmed A.R. (2011). Utilization of decorticated pigeon pea (Cajanu scajan L.) with wheat (Triticum aestivum) flours in bread making. Adv. J. Food Sci. and Tech., 3 (6): 413-417.

Hussein A.M.S, Kamil M.M., Hegazy Nefisa A. and Abo El-Nor S.A.H. (2013). Effect of wheat flour supplemented with barley and/or corn flour on balady bread quality. Polish J. Food and Nutr. Sci., 63 (1): 1118.

Imada S. and Takahshi M. (1986). Effects of extract of rice bran vinegar on the texture of agar gel of seaweed Ceramium boydenii. J. Japanese Soci. Nutr. and Food Scie., 39 (2): 107-114.

Jones R.W. and Erlander S. R. (1967). Interactions between wheat proteins and dextrains. Cereal Chemistry, 44: 447-456.

Kent-Jones D.W. and Amos A.J. (1967). Modem Cereal Chemistry. $6^{\text {th }} \mathrm{Ed}$. The Norten Sublising Co., Liver,Pool, London, UK.

Khairy Hanan M. and El-Shafay Shimaa M. (2013). Seasonal variations in the biochemical composition of some common seaweed species from the coast of Abu Qir Bay, Alexandria, Egypt, Polish Academy of Science, Institute of Oceanology, 435-452.

Kushi M. (1986). The Book of Macrobiotics, Japan Publ., Tokyo, New York, USA. pp.83-86.

Kovac D. J., Simeunovic J.B., Babic O.B., Misan A. C. and Milovanovic I., Lj. (2013). Algae in food and feed. Food and Feed Res., 40 (1): 21-31.

Lahaye M. and Kaeffer B. (1997). Seaweed dietary fibres: structure, physico-chemical and biological properties relevant to intestinal physiology. Sciences des Aliments, 17 (6): 563-584.

León A.E., Ribotta P.D., Ausar S.F., Fernández, C., Lanada C.A. and Beltramo, D.M. (2000). Interactions of different carrageenan isoforms and flour components in breadmaking. J. Agric. Food Chem. 48: 2634-2638.

Mahgoub S.E.O. (1999). Production and evaluation of weaning foods based on sorghum and legumes. Plant Foods for 
Human Nutr., 54: 29-42.

Murata M. and Nakazoe J. (2001). Production and use of marine algae in japan. Japan Agric. Res. Quart., 35(4): 281- 290.

Nguyen P. M. (2014). Effect of Saccharomyces cerevisiae, Spirulina and preservative supplementation to sweet bread quality in bakery. Inter`l J. Multidisciplinary Res. and Develop. 2014; 1(4): 36-44

Ortega-Calvo ,J.J., Mazuelos C., Hermosin B. and Saiz- Jimenez C. (1993). Chemical composition of Spirulina and eukaryotic algae food products marketed in spain. Journal of Applied Phycology, 5: 425435.

Ozols J. (1990). Amino acid analysis. In: Guide to Protein Purification, Methods in Enzymology, (Murray, P.D., editor). Vol. 182, Academic Press, London. England, pp. 587-601.

Perten H. (1990). Rapid measurement of wet gluten quality by the gluten index. Cereal Foods World, 35 (4): 401-402.

Plaza M.., Cifuentes A. and Ibanez E. (2008). In the search of new functional food ingredients from algae. Trends in Food Scie. and Techn., 19(1):31-39.

Rosell C.M., Rojas J.A. and Benedito C. (2001). Influence of hydrocolloids on dough rheology and bread quality. Food Hydrocolloids, 15:75-81.

Rupérez P. (2002). Mineral content of edible marine seaweeds Original Research Article, Food Chem. ,79: 23-26.
Sangnark A. and Noomhorn A. (2004). Chemical, physical and baking properties of dietary fiber prepared from rice straw, Food Res. Inter`1, 37: 66-74.

Seleem H.A.S. (2000). Studies on addition of some corn and sorghum varieties to wheat flour and balady bread characteristic. Ph.D. Thesis, Fac.of Agric., Cairo Univ., Egypt.

Selomulyo V.O. and Zhou W. (2007). Frozen bread dough: effects of freezing storage and dough improvers. J. Cereal Sci. 45:117.

Serrem C., Kock H. and Taylor J. (2011). Nutritional quality, sensory quality and consumer acceptability of sorghum and bread wheat biscuits fortified with defatted soy flour. Inter`1. J. of Food Scie. and Tech., 46: 74-83.

Sudha M., Vetrimani R. and Leelavathi K. (2007). Influence of fibre fromdifferent cereals on the rheological characteristics of wheatflour dough and on biscuit quality. Food Chem., 100(4):1365- 1370.

Whitney E.N. and Rolfes S.R. (1996). The fatsoluble vitamins: A, D, E, and K. In: Understanding Nutrition, Whitney, E.N and Rolfes, S.R.,(edit..). Pp393-428, West Minneapolis/St Paul, MN.,USA.

Yaseen A.A. (1985). Chemical and physical studies on the characteristics of balady bread. M.Sc. Thesis, Fac. Agric., Ain Shams Univ., Egypt. 
إثراء القيمة الغذائية للخبز باستخدام الطحالب الحمراء

\section{ناهد سامى يوسفـ- رباب حسن سالم ـ منال حجاج عبد القادر*ـ ايمان محمد ابراهيم ابو زيد}

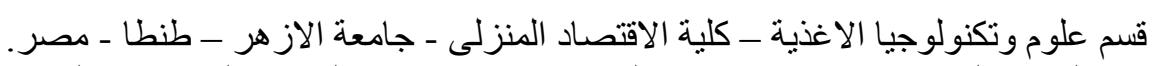

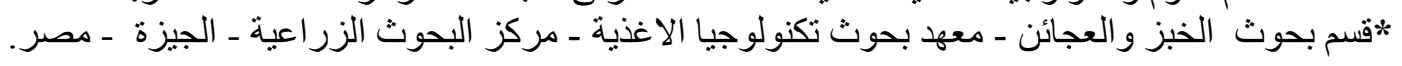

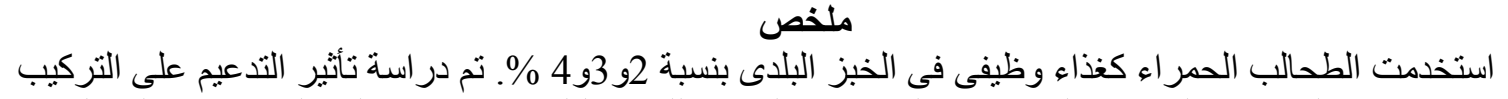

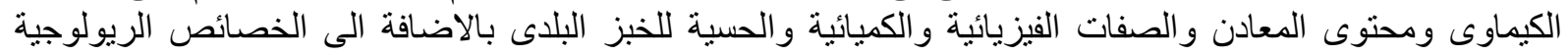

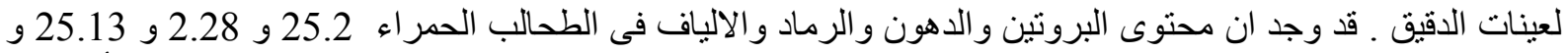

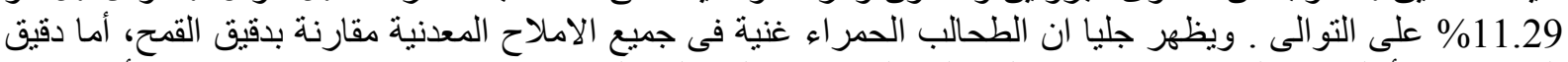

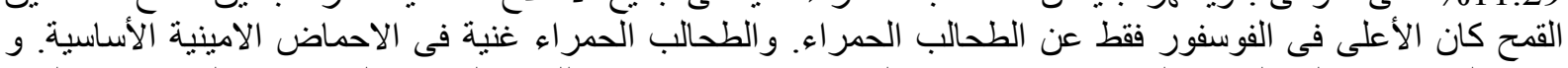

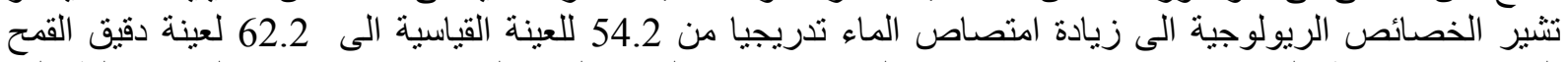

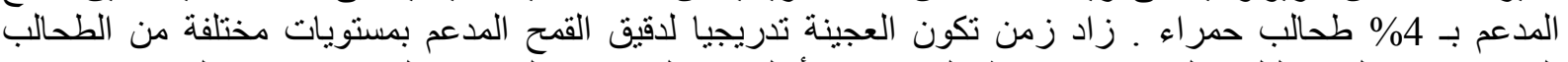

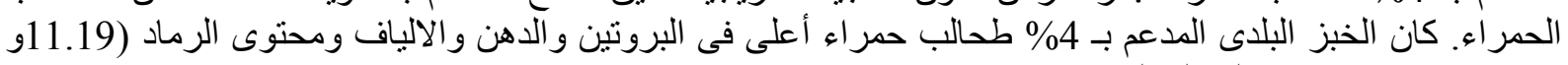

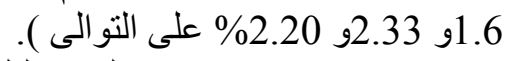

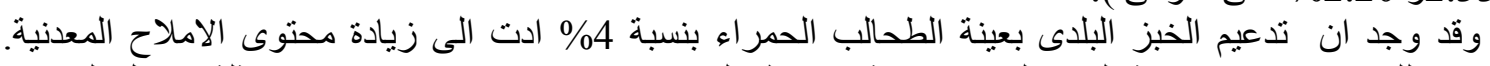

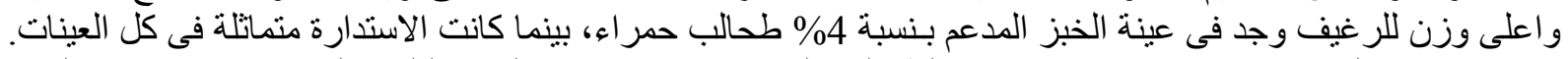

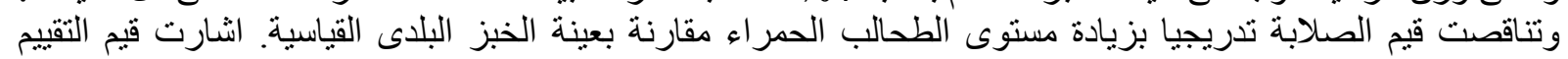

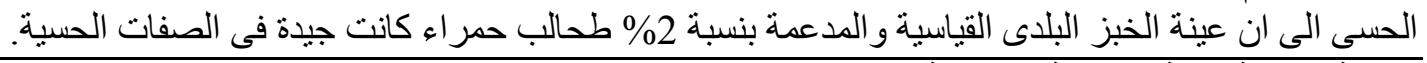

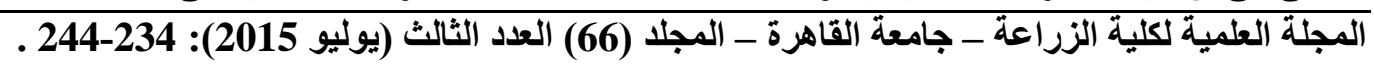

